\title{
Cue the Elephant! Backstage Tales at the CBC
}

\author{
By Gerald Pratley
}

Spring 1997 Issue of KINEMA

BY an interesting co-incidence, on taking up Knowlton Nash's Cue the Elephant!, the pages fell open at the story of Norman Jewison's difficulties with General Electric when it objected to his "sexy and impudent" shows and his decision to use writer Reuben Ship, who had been blacklisted in the US as a communist. The CBC should never be at the mercy of sponsors and their hucksters -- as it so frequently has been and still is!

Nash's book is what it claims to be: Backstage Tales at the CBC. His previous work, The Microphone Wars (1994) was his history of the Corporation. The new book is about the artists and celebrities, from John Drainie to the Happy Gang and on to The Royal Canadian Air Farce, who brought CBC radio and television to life and became its bright personalities and stars. The younger generation of today will never have heard of most of them, but should know of them, while the older generation will remember and recall them with pleasure.

It's surprising and encouraging to see how many of the famous, and the not so well-known, are still at work, who remained in Canada (not that one can blame those who left) and gave us characters, voices, expressions and a sense of place that we recognised and remember as being our way of communicating with each other through our radio and television.

Some of their backstage stories were funny when they happened, and funnier when told over the years among each other with the natural exaggerations which come with twice-told tales, but others are not terribly witty or insightful and have tired with the passing of time and repetition.

But the whole brings back the promises of the exciting pioneer years when Ottawa seemed far away and out of the picture, control was in the Kremlin (the old house on Jarvis Street) among those we knew, and before the selling-out of our programming to the Americans (instead of turning to the NFB) and where our sense of purpose and direction lay entirely within our borders.

But for Tony Manera, watching CBC comfortably at home these winter nights without worries and responsibilities, it must give him some satisfaction to see the evening schedules now filled almost entirely with watchable Canadian films and programmes and for which he surely deserves credit -- but still broken up with intrusive and unwanted commercials.

\section{Also worth reading:}

More back-stage stuff: SCTV: Behind the Scenes by Dave Thomas (McLelland \& Stewart) is better with candid anecdotes than funny stories in its revealing descriptions of the working methods and relationships involving this famous group. Its leading light, the immensely comic John Candy, is the subject of Martin Knelman's Laughing on the Outside, a balanced biography of his life and career. (Viking-Penguin)

In Risk and Redemption, Arthur Kent (formerly with CBC) tells of his battle over integrity in the news department of NBC and how he emerged much the richer as a result of its treatment of him. (VikingPenguin)

Tom Daly of the National Film Board is The Best Butler in the Business (by D.B. Jones, University of Toronto Press) in a thorough career consideration of one of the NFB's first editors and producers who has gone from the almost primitive equipment of the early years to the complicated techniques of the present.

Among these digital discoveries one seldom stops to think of the many scientific filmmakers involved in their use and development in the making of the dozens of wild-life series seen constantly on television. One was the late Bill Mason whose lifelong devotion to recording nature is engrossingly told by James Raffan in Fire in the Bones (Harper Collins). 


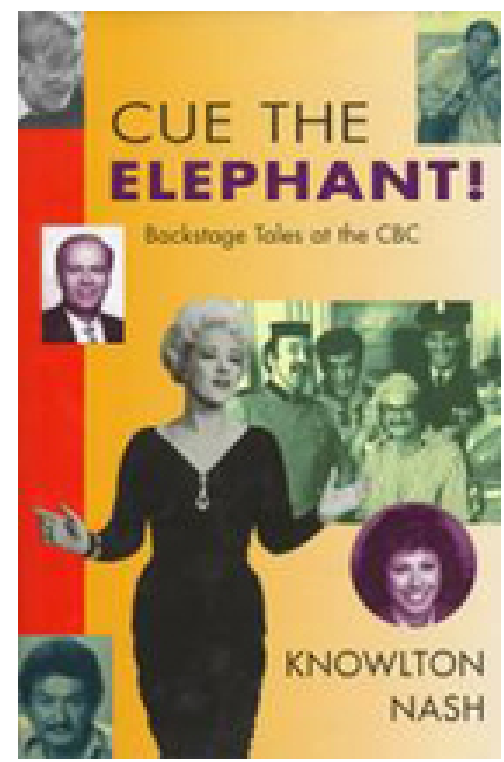

Figure 1: TITLE: Cue The Elephant! Backstage Tales at the CBC 9 BY: Knowlton Nash 9 PUBLISHER: Toronto: McClelland and Stewart \ YEAR: 1996 ฯ PAGES: 308pp I ISBN: 0-7710-6734-8 ๆ PRICE: CAD 22.95 (paper)

\section{Author Information}

Gerald PRATLEY, OC, LLD, started his career as film critic with the CBC. In 1969, he founded the Ontario Film Institute which he directed until 1990. He has written several books and numerous articles on film, including Torn Sprockets, a history of Canadian cinema. He taught Film History in universities in Toronto and Waterloo, Canada and holds three honorary degrees from Canadian and US universities.

Gerald A. Pratley (1923-2011) was born and educated in London, England, and came to Canada in 1946. He started working in Toronto for the $\mathrm{CBC}$ as a scriptwriter. He was drawn toward working in motion pictures, and became, in 1948, the CBC's first film critic and commentator.

Gerald Pratley broadcast three programmes a week, Pratley at the Movies, The Movie Scene, Music From the Films, and others, until 1975. During this time he also became the first post-war chairman of the Toronto Film Society, chairman of the Toronto and District Film Council and co-founder of the A-G-E Film Society and correspondent for international magazines such as Films and Filming, Film In Review, Variety, Hollywood Quarterly and International Film Guide. During the 1950s he wrote for Canadian Film Weekly and Canadian Film Digest.

He became known as a speaker on all aspects of motion picture art and industry, and was invited to teach film history at the University of Toronto, York University, University of Waterloo, Seneca College and Ryerson Polytechnical University, with individual lectures being given at many other Canadian and US universities and colleges. He has served as a member of various judging panels of competitions and festivals, being one of the members of the first Canadian Film Awards in 1949.

From 1970 to 1975 he was the director of the Stratford (Ontario) International Film Festival, and from 1969 to 1976 he was Chairman of the International Jury of the Canadian Film Awards. He has attended all the world's leading festivals of film, and in particular, for 30 years, the Cannes Festival as CBC correspondent. He has written six books, The Films of Frankenheimer: Forty Years in Film; The Cinema of John Frankenheimer; The Cinema of Otto Preminger; The Cinema of David Lean; The Cinema of John Huston, and Torn Sprockets, a history of the Canadian cinema.

Gerald Pratley has served on the Advisory Boards of the film departments of Ryerson Polytechnical University and Humber College, and as a member of the programme committee of TV Ontario. In 1968 he became 
the founder-director of the Ontario Film Institute of the Province of Ontario, an organization which has distinguished itself in archival holdings and public service and is known since 1990 as the Cinematheque of Ontario. He taught Film History courses at the Department of Film and Photography, Ryerson Polytechnic University, Toronto and the University of Waterloo.

In 1984, Gerald Pratley was made a Member of the Order of Canada and in 2003 Officer of the Order of Canada for his service to Canada through film appreciation. He holds Honorary Degrees in Letters and Fine Arts from York and Waterloo Universities (Ont., Canada) and Bowling Green State University (Ohio, USA).

In 2002, Gerald Pratley received a Special Genie Award from the Academy of Canadian Cinema \& Television in recognition of his lifelong dedication to the promotion and his exceptional support of Canadian cinema.

He died on 14 March 2011 in Ontario, Canada. 